\title{
PERLINDUNGAN HUKUM TERHADAP KAUM DIFABEL KORBAN PEMERKOSAAN
}

\author{
Legal Protection to the Disabled Rape Victims
}

\author{
Alfan Alfian \\ Rejowinangun, RT/RW: 03/05, Kemiri, Purworejo, Jawa Tengah \\ email: alfianalfan.aa@gmail.com
}

\begin{abstract}
In Indonesia arrangement on Human Rights has been included in the constitution, starting from Article 28A to 28J, even re-clarified in Article 29 of the Constitution of 1945. Viewing of the formulation of articles in the 1945 Constitution, suggests that there is injury history so deep against human rights enforcement in Indonesia before the reform, thus setting Human Rights was included as detailed in the constitution that should only set the rules subject. Associated with the handling of victims with disabilities before the law, into a constitutional basis that disabled people should be applied equally before the law, even if not physically perfect and different from normal people as usual. Protection against disabilities, actually are not discussed explicitly in the constitution, but the Legal Power is in our constitution has leads to there, so some sectorial laws need to be explain to specifically.
\end{abstract}

Keywords: Legal Protection, Disability, Rape

\section{abstrak}

Di Indonesia pengaturan tentang Hak Asasi Manusia sudah sedemikian rupa dicantumkan dalam konstitusi, yaitu mulai dari Pasal 28A hingga 28J, bahkan diperjelas ulang pada Pasal 29 Undang-Undang Dasar 1945. Melihat dari rumusan pasal di dalam UUD 1945 tersebut, memberikan gambaran bahwa ada luka sejarah yang begitu mendalam terhadap penegakkan HAM di Indonesia sebelum reformasi, sehingga pengaturan Hak Asasi Manusia pun dicantumkan begitu detail di dalam konstitusi yang seharusnya hanya mengatur aturan pokok saja. Terkait dengan perlakuan korban difabel di muka hukum, menjadi dasar konstitusional bahwa kaum difabel harus diberlakukan sama dimuka hukum, walaupun secara fisik tidak sempurna dan berbeda dengan masyarakat normal seperti biasa. Perlindungan terhadap difabel sebenarnya memang tidak dibicarakan secara eksplisit di dalam undang-undang dasar, namun Legal Power yang ada di dalam konstitusi kita sudah mengarah kesana, sehingga beberapa undang-undang sektoral perlu menjelaskan secara spesifik. 
Kata Kunci: Perlindungan Hukum, Difabel, Pemerkosaan

\section{A. Pendahuluan}

Indonesia merupakan salah satu negara modern di dunia yang menempatkan hukum sebagai panglima. Artinya bahwa hukum harus dilaksanakan untuk menegakkan keadilan, kepastian dan kemanfaatan. ${ }^{1}$ Seperti yang diutarakan oleh Gustav Radbruch bahwa ketika tiga tipologi tujuan hukum tersebut tercapai, maka hukum akan menemukan rohnya. Hukum sudah tidak lagi hanya menjadi deretan tulisan naratif yang tak ternilai apa-apa. Ukuran atau barometer efektifitas terjalinnya tujuan hukum Friedman juga mengutarakan sebuah Legal System Theory yang menekankan pada tiga aspek yaitu yang pertama, Legal Subtantive yaitu terkait pada substanti pengaturan hukum seperti pada peraturan perundang-undangan, kedua Legal Structure yang mana dalam penegakkan hukum perlu adanya instrumen-instrumen yang dibutuhkan seperti kepolisian yang melakukan penyidikan, kejaksaan bagian penuntutan, advokat pembelaan, atau hakim sebagai pemutus perkara, dan yang terakhir terkait Legal Culture atau budaya hukum. ${ }^{2}$ Pada term kedua yang kemudian perlu menjadi perhatian serius akhir-akhir ini.

Tentang Law Enforcement di Indonesia masih banyak perlu perbaikan baik dari keorganisasian maupun Attitude para artor-aktor perorangan di masing-masing institusi. Sebagai konsekuensi negara hukum, pemberlakuan asas equality before the law harus menjadi garda paling depan. persamaan di muka hukum, anti diskriminasi artinya tidak ada perbedaan atas siapa pun yang mendapat perkara, mulai dari perlakuan penyidikan hingga sidang di pengadilan. Menurut hemat penyusun ada beberapa hal yang dapat memengaruhi terjadi perlakuan diskriminasi dalam dalam proses penanganan hukum, namun ada satu yang yang sering terjadi karena dari tersangka, terdakwa atau pun terpidana, bahkan seorang korban yang merupakan kalangan orang yang lemah, rentan, dan atau kurangnya pengetahuan. Korban-korban ini sering ditemui pada kalangan difabel yang mendapatkan perlakuan diskriminasi dan kekurangan hak-haknya karena memang aksesnya terhambat.

Persoalan menjadi serius jika hal ini hanya dibiarkan tanpa adanya tindakan tegas dari pemerintah untuk menempatkan kaum difabel mendapatkan akses publik sebanyak-banyaknya, khususnya pada dalam menegakkan hukum, karena mereka juga bagian dari para justiciable yang dilindungi oleh konstitusi. Undang-Undang Nomor 13 Tahun 2006 tentang

\footnotetext{
${ }^{1}$ Martitah, Dari Negative Legislature Ke Positive Legislature, (Jakarta: Mahkamah Konstitusi Press, 2013), hlm. 63.

${ }^{2}$ Ibid., hlm 89.
} 
Perlindungan Saksi dan Korban memang sudah disahkan. Undang-undang tersebut untuk melindungi setiap orang yang menjadi korban dari ancaram untuk menjadi korban kembali, dengan hak-hak yang diberikan seperti mendapatkan penerjemah, cuplikan putusan, rehabilitasi hingga restitusi. Ratifikasi perjanjian internasional juga telah dilakukan pemerintah yaitu Convention on The Rights of Person with Disabilities (Konvensi Mengenai Hak-Hak Penyandang Disabilitas). Walaupun berbagai upaya pemerintah dalam melindungi kaum difabel yang menjadi korban tindak pidana sudah demikian dilakukan namun masih saja peraturan yang dibuat dalam praktiknya selalu mendapat kendala. Oleh karena itu penyusun akan membidik lebih jauh terkait perlindungan hukum terhadap kaum difabel korban pemerkosaan, baik dalam peraturan maupun langsung pada praktiknya. Penyusun juga akan sedikit memberikan komparasi dengan beberapa negara lain terkait perlindungan hukum kaum difabel. Berdasarkan pemaparan latar belakang di atas maka sangat menarik untuk dikaji lebih mendalam tentang bagaimanakah perlindungan hukum terhadap kaum difabel korban pemerkosaan.

\section{B. Pembahasan}

\section{Bentuk Perlindungan Hukum Terhadap Difabel Korban Tindak Pidana Kesusilaan}

Seperti yang sudah dijelaskan sebelumnya bahwa Indonesia sudah memproklamirkan sendiri sebagai negara hukum. Hal tersebut membawa konsekuensi logis terhadap segala aktifitas kegiatan pemerintahan harus berdasarkan dengan hukum itu sendiri. Menurut Franz Magnis Suseno, bahwa ada empat syarat dalam gagasan negara hukum yang saling berhubungan satu sama lain, yaitu pertama, adanya Asas Legalitas yang berarti pemerintah bertindak semata-mata atas dasar hukum yang berlaku; kedua, adanya kebebasan dan kemandirian kekuasaan kehakiman terutama dalam fungsinya untuk menegakkan hukum dan keadilan; ketiga, adanya jaminan perlindungan terhadap hak-hak asasi manusia; dan keempat, adanya pemerintahan berdasarkan sistem konstitusi atau hukum dasar. ${ }^{3}$ Ada persamaan yang mencolok antara konsepsi Negara Hukum Suseno dengan konsep yang sudah diutarakan oleh Julius Stahl, ataupun A.V. Decey tentang Negara Hukum. Mereka sama-sama menempatkan Hak Asasi Manusia sebagai term yang perlu diperjuangkan dalam memberlakukan negara hukum. Intinya bahwa penegakkan hak asasi manusia sudah tidak bisa ditawar-tawar lagi.

\footnotetext{
${ }^{3}$ Franz Magnis- Suseno, Etika Politik: Prinsip Moral Dasar Kenegaraan Modern, (Jakarta: Gramedia, 1993), hlm. 298-301
} 
Untuk mencapai To Keep Goverment In Order, di Indonesia pengaturan tentang Hak Asasi Manusia sudah sedemikian rupa dicantumkan dalam konstitusi kita, yaitu mulai dari Pasal 28A hingga 28J, bahkan diperjelas ulang pada Pasal 29 Undang-Undang Dasar 1945. Melihat dari rumusan pasal di dalam UUD 1945 tersebut, memberikan gambaran bahwa ada luka sejarah yang begitu mendalam terhadap penegakkan HAM di Indonesia sebelum reformasi, sehingga pengaturan Hak Asasi Manusia pun dicantumkan begitu detail di dalam konstitusi yang seharusnya hanya mengatur aturan pokok saja. Kita masih ingat bahwa sebelum reformasi khususnya pada Orde Baru, bagaimana pengaturan HAM diberlakukan, bahwa tidak adanya transparansi pemerintah, bahkan hak individu dibungkam rapat-rapat. Hingga tidak ada persamaan di depan hukum, hanya kalangan elit saja yang diperlakukan istimewa karena punya uang dan mampu mengurus perkara hingga ke jenjang kasasi. Namun, Pasca reformasi, para perancang naskah konstitusi menentukan skenario terbaik dalam menjamin orisinalitas kemauan rakyat. Setiap individu memiliki hak yang sama di hadapan hukum tanpa melihat status sosial (Jabatan), RAS, Agama, dan atau golongan tertentu. Hal tersebut sejalan dengan pasal 28D ayat (1) dan 28I ayat (2) UUD 1945 berbunyi:

"Setiap orang berhak atas pengakuan, jaminan, perlindungan, dan kepastian hukum yang adil serta perlakukan yang sama di hadapan hukum",

"Setiap orang berhak bebas dari perlakuan yang bersifat diskriminatif atas dasar apapun dan berhak mendapatkan perlindungan terhadap perlakuan yang bersifat diskriminatif"

Pasal di atas kemudian terkait dengan perlakuan korban difabel di muka hukum, menjadi dasar konstitusional bahwa kaum difabel harus diberlakukan sama di muka hukum, walaupun secara fisik tidak sempurna dan berbeda dengan masyarakat normal seperti biasa. Perlindungan terhadap difabel sebenarnya memang tidak dibicarakan secara eksplisit di dalam undang-undang dasar, namun Legal Power yang ada di dalam konstitusi kita sudah mengarah ke sana, sehingga beberapa undang-undang sektoral perlu menjelaskan secara spesifik. Seperti pada Undang-Undang Nomor 39 Tahun 1999 tentang Hak Asasi Manusia khususnya pada Pasal 5 ayat (3) mengatakan "setiap orang yang termasuk kelompok masyarakat yang rentan berhak memperoleh perlakuan dan perlindungan lebih berkenaan dengan kekhususannya." Pada penjelasan pasal tersebut semakin mempertegas bahwa penyandang cacat adalah salah satu kelompok masyarakat rentan yang berhak untuk memperoleh perlindungan yang lebih dan khusus.

Pada salah satu asas hukum pidana, yang juga merupakan asas legalitas, Nullum delictum, noela poena sine lege praevia, bahwa tidak ada suatu pidana kecuali sudah ada undang-undang yang mengaturnya. Dasar 
tersebut kemudian menjadi penting bahwa suatu perbuatan pidana harus dirumuskan dalam satu uraian pasal pada peraturan perundang-undangan. Terkait dengan Pengaturan mengenai difabel yang berhadapan dengan hukum diatur pula pada Pasal 5 Undang-Undang Nomor 4 Tahun 1997 tentang Penyandang Cacat dan Penjelasan Pasal 5 Undang-Undang Nomor 4 Tahun 1997 tentang Penyandang Cacat yang mengatur bahwa setiap penyandang cacat memunyai hak dan kesempatan yang sama dalam segala aspek kehidupan dan penghidupan yang meliputi aspek agama, kesehatan, pendidikan, sosial, ketenagakerjaan, ekonomi, pelayanan umum, hukum, budaya, politik, pertahanan keamanan, olah raga, rekreasi, dan informasi. Peraturan yang mengatur difabel pada Pasal 5 Undang-Undang Nomor 4 Tahun 1997 tentang Penyandang Cacat dan penjelasan Pasal 5 UndangUndang Nomor 4 Tahun 1997 tentang Penyandang Cacat hanya menitikberatkan pada kesejahteraan sosial kaum difabel sedangkan untuk difabel yang berhadapan dengan hukum belum diatur secara khusus.

Oleh karena wujud kepedulian negara terhadap kaum minoritas tersebut, maka pemerintah meratifikasi perjanjian internasional yang diturunkan pada Undang-Undang Nomor 19 Tahun 2011 tentang Pengesahan Convention on The Rights of Person with Disabilities (Konvensi Mengenai Hak-Hak Penyandang Disabilitas). Pada pasal 5 konvensi tersebut pada intinya mengatakan negara-negara pihak mengakui bahwa semua manusia adalah sama. Selain itu, negara-negara pihak wajib mencegah semua diskriminasi yang fundamental terhadap kaum disbilitas serta menjamin perlindungan hukum yang sama dan efektif bagi penyandang disabilitas. Menurut penyusun, pengaturan tersebut memang memberikan legitimasi terhadap kaum disabilitas untuk tidak diberlakukan berbeda sebagaimana masyarakat normal seperti biasanya, namun penyusun belum menemukan adanya pengaturan mengenai penerapan saksi hukum terhadap pelaku tindak pidana kaum difabel sehingga mengakibatkan terhambatnya kinerja kepolisian, kejaksaan dan pengadilan dalam melakukan perlindungan terhadap kaum difabel.

Apabila saksi dan korban dijelaskan pada undang-undang hasil ratifikasi tersebut, maka tentu akan mempermudah kepolisian kejaksaan atau institusi penegak hukum yang lain untuk melengkapi properti-properti dan prosedur khusus yang diperlukan dalam menangani kaum difabel yag tersangkut perkara tertentu. Dalam hal ini dapat pula dibuat kamar khusus untuk menangani kasus tersebut, karena sumberdaya manusia yang dipakai harus khusus pula seperti kepiawaian bahasa isyarat dan ahli psikologi yang tahu keadaan jiwa difabel tertentu yang terkadang tidak sesuai dengan usia yang sedang disandangnya sekarang.

Sejauh ini undang-undang yang paling banyak digunakan dalam melakukan perlindungan saksi dan korban adalah Undang-Undang Nomor 
13 Tahun 2006 tentang Perlindungan Saksi dan Korban. Adapun perlindungan terhadap korban dan saksi tertera pada Pasal 5 ayat (1) mengatakan bahwa Seorang Saksi dan Korban berhak:

a. memperoleh perlindungan atas keamanan pribadi, keluarga, dan harta bendanya, serta bebas dari ancaman yang berkenaan dengan kesaksian yang akan, sedang, atau telah diberikannya;

b. ikut serta dalam proses memilih dan menentukan bentuk perlindungan dan dukungan keamanan;

c. memberikan keterangan tanpa tekanan;

d. mendapat penerjemah;

e. bebas dari pertanyaan yang menjerat;

f. mendapatkan informasi mengenai perkembangan kasus;

g. mendapatkan informasi mengenai putusan pengadilan;

h. mengetahui dalam hal terpidana dibebaskan;

i. mendapat identitas baru;

j. mendapatkan tempat kediaman baru;

k. memperoleh penggantian biaya transportasi sesuai dengan kebutuhan;

1. mendapat nasihat hukum; dan/atau

m. memperoleh bantuan biaya hidup sementara sampai batas waktu perlindungan berakhir.

Pada ayat (2) mengatakan bahwa Hak sebagaimana dimaksud pada ayat (1) diberikan kepada Saksi dan/atau Korban tindak pidana dalam kasuskasus tertentu sesuai dengan keputusan LPSK (lembaga perlindungan saksi dan korban). Perlindungan lain dapat ditemukan pada Pasal 6 ayat (1) bahwa Korban dalam pelanggaran hak asasi manusia yang berat, selain berhak atas hak sebagaimana dimaksud dalam Pasal 5, juga berhak untuk mendapatkan: bantuan medis; dan bantuan rehabilitasi psiko-sosial. Perlindungan dan hak saksi dan korban diberikan sejak tahap penyelidikan dimulai dan berakhir sesuai dengan ketentuan sebagaimana diatur dalam undang-undang ini.

Pada undang-undang ini, yang dimaksud saksi dan korban hanya ditujukan pada seseorang, sehingga menurut penyusun walaupun secara bunyi pasal tidak tercantum orang cacat atau difabel, maka pasal tersebut bersifat universal mengikat bagi semua pihak yang diposisikan sebagai korban yang mengalami penderitaan fisik atau psikis atas tindak pidana tertentu. Hal ini juga sering kali digunakan oleh jaksa untuk merumuskan pasal tuntutan sebagai delik biasa walaupun terjadi pada tindak pidana terhadap difabel. Peranan korban pada undang-undang tersebut dituntut untuk bersifat kooperatif. Artinya bahwa harus ada tindakan sendiri oleh korban di dalam sistem peradilan pidana yang dimaksud. Dalam arena ini pengajuan rehabilitasi akan ditindaklanjuti jika korban mengajukan sendiri melalui LPSK menuju ke pengadilan. Model perlindungan ini sangat menitikberatkan pada partisipasi korban itu sendiri 
Di Indonesia sesuai dengan peraturan yang sudah ada ternyata ditemukan masih ada banyak kelemahan dalam perlindungan hukum terhadap korban difabel itu sendiri. Kasus pemerkosaan atau kasus lain mengenai tindakan pidana kesusilaan yang didalamnya difabel pun sama saja jenis perlindungannya, yaitu tetap menggunakan dasar aturan yang sudah ada. Delik yang digunakan jaksa penuntut umum juga masih menggunakan KUHP (Kitab Undang-undang Hukum Pidana) sebagaimana tertera pada Pasal yang dimaksud. Hal ini tentu tidak sesuai dengan tujuan dari Sistem Peradilan Pidana itu sendiri. Menurut Marcus tujuan dari sistem peradilan pidana adalah sebagai berkut: ${ }^{4}$

a. melindungi masyarakat melalui penanganan dan pencegahan kejahatan, merehabilitasi pelaku kejahatan, dan melakukan upaya inkapasitasi terhadap orang yang merupakan ancaman terhadap masyarakat;

b. menegakkan dan memajukan the rule of law dan penghormatan pada hukum, dengan menjamin adanya due process dan perlakuan yang wajar bagi tersangka, terdakwa dan terpidana, melakukan penuntutan dan membebaskan orang yang tidak bersalah yang dituduh melakukan kejahatan;

c. menjaga hukum dan ketertiban;

d. menghukum pelaku kejahatan sesuai dengan falsafah pemidanaan yang dianut; dan

e. membantu dan memberi nasihat pada korban kejahatan.

Dari pemaparan tujuan sistem peradilan pidana ternyata korban juga merupakan bidikan utama yang harus dibantu dan diberi nasihat. Artinya bahwa sebenarnya melalui sistem peradilan pidana posisi korban dapat lebih diuntungkan dan mencegah terjadinya korban berikutnya. Selain itu harus ada penanganan tertentu terhadap difabel yang tersangkut kasus pidana. Para penegak hukum juga harus Balance dalam menangani kasus pidana antara pelaku (offender) dan Korban (victim), apalagi jika posisi korban adalah pihak yang rentan seperti kaum difabel.

Perlindungan di Negara Indonesia terhadap kaum difabel sampai hari ini masih dirasa kurang. Hal ini begitu jelas ketika dibandingkan dengan negara lain seperti di di Amerika Serikat (AS), misalnya, ada UU khusus untuk melindungi kaum difabel yang bernama The American with Disabilities Act. UU ini berisi kewajiban negara untuk memberikan perlindungan bagi kaum difabel di bidang pendidikan. AS bahkan melengkapi perlindungan untuk mahasiswa/mahasiswi difabel dengan yayasan yang bernama The Learning Disabilities Association of American. Dengan adanya perlindungan itu, di beberapa kampus AS, seperti St Francis

\footnotetext{
${ }^{4}$ Disampaikan oleh Prof Marcus, Pada Kuliah Sekolah Pasca Sarjana/Magister Ilmu Hukum Universitas Gadjah Mada Yogyakarta, Rabu, 3 Desember 2014, Pukul 11.00 WIB.
} 
Xavier University dan University of Washington, melindungi dan membantu mahasiswa difabel untuk menuntut ilmu setinggi-tingginya. Di University of Washington, sejak 1978 sudah memodifikasi sedemikian rupa lingkungan kampusnya agar ramah difabel. Hal itu, misalnya, kondisi jalanan yang rata dan tidak berbukit-bukit, serta fasilitas mobil jemputan khusus. Fasilitas ini untuk memudahkan kaum difabel yang memiliki kesulitan mobilitas, kemudahan dalam mengakses teknologi, baik di laboratorium, maupun perpustakaan khusus yang membantu penyandang tunanetra dan tunarungu, parkir khusus, dan konseling akademis. Akses-akses yang diberikan ini membantu pula para kaum difabel terpelajar di Amerika untuk dapat ikut serta dalam mengawal jalannya sistem peradilan yang ada di sana seperti terkait register perkara dan berkas penuntukan yang begitu mudah didapatkan. $^{5}$

Di Neitherland untuk korban kejahatan kekerasan khusus yang dilakukan dengan sengaja disediakan dana oleh departemen kehakiman pada UU "wet voorlopige regeling schadefonds geweld misdrijven" (wet 26 juni 1975. Stb 382). Kejahatan khusus tersebut dapat dianalogikan sebagai kejahatan yang korbannya adalah orang tidak normal, orang cacat, dan sebagainya. ${ }^{6}$ Peranan Negara Belanda terhadap korban cukup besar, karena bersentuhan langsung kepada korban, memberi santunan agar nilai keseimbangan antara korban dan pelaku lebih terjamin. Selain pelaku sudah diproses secara hukum melalui pengadilan, korban pun mendapat mendapat santunan bahkan hingga rehabilitasi yang dapat mengembalikan korban ke posisi normal seperti semua baik jasmani maupun rohani. Model seperti ini sering disebut dengan model perlindungan Services Model. Adapun bentuk perlindungan yang nyata pada model ini berupa ganti rugi yang diberikan oleh negara dan bantuan hukum seperti yang tercantum dalam undangundang perlindungan saksi dan korban. Orientasi Sevices Model ini untuk memberikan pelayanan publik yang baik dan untuk dapat membantu terwujudnya integrity of the system of institutionalized trust. ${ }^{7}$

Berbeda di Indonesia yang lebih condong menggunakan Prosedural Right Model yang mana korban memiliki hak hukum dalam setiap tahapan proses peradilan (hak bantuan hukum dan sebagainya). Kemudian dalam model ini korban dapat terlibat langsung dalam proses peradilan. Dengan demikian polisi dan jaksa diwajibkan untuk memperhatikan hak-hak korban, serta diwajibkan untuk pemenuhan. Polisi dan jaksa menjadi garda yang

\footnotetext{
${ }^{5}$ Diakses pada situs www.SinarHarapan.com, oleh Agus Wibowo, dengan tema Diskriminasi Pendidikan Bagi Kaum Difabel, Kamis, 4 Desember 2014.

${ }^{6}$ Arif gosita, Masalah Korban Kejahatan Edisi Pertama, (Jakarta: Akademika Pressindo, 1983), hlm. 87.

${ }^{7}$ Muladi, Barda Nawawi Arief, Bunga Rampai Hukum Pidana, (Bandung: Alumni, 2010), hlm. 83-87.
} 
paling depan dalam menyukseskan model perlindungan ini. Namun, seringkali jauh panggang dari api, polisi maupun korban sering mengabaikan partisipasi korban karena dengan alasan mengganggu pelayanan publik. Begitulah barang barang kali yang sering terjadi di dalam praktik, oleh karena itu terkait dengan praktik perlindungan hukum terhadap koban difabel akan dikupas di dalam sub-bab selanjutnya dengan pegangan putusan pengadilan.

\section{Perlindungan Hukum terhadap Korban Difabel Perkosaan di dalam Praktik Berdasarkan Putusan Putusan Nomor 244/Pid2013/P.T.Smg.}

Jauh setelah melihat dan mengaji peraturan perundang-undangan yang ada mengenai perlindungan hukum terhadap korban difabel pemerkosaan, penyusun mengatakan peraturannya sudah sedemikian rupa akomodatif. Khususnya upaya pemerintah dalam meratifikasi Convention on The Rights of Person with Disabilities (Konvensi Mengenai Hak-Hak Penyandang Disabilitas). Hal tersebut menjadi jawaban bahwa tugas negara dalam memberlakukan sebagai Indonesia sebagai negara hukum, menempatkan kaum difabel sebagai aset negara, dan bukan sebagai beban negara. Selain itu secara demografis, seperti yang sudah direalisasi oleh Metrotv News bahwa laporan Bank Dunia dan PBB, khususnya WHO pada 2011 mengenali jumlah difabel di dunia adalah 15 persen dari total populasi dunia. Sedangkan total populasi Indonesia yang saat sensus tahun 2010 lalu berada di angka 237,6 juta, jika diambil 15 persennya, artinya jumlah difabel di Indonesia berada di kisaran 35,7 juta orang. ${ }^{8}$

Intinya bahwa, jika pengaturan tentang perlindungan difabel sudah sedemikian rupa dituliskan apabila dalam tataran implementasi tidak dilakukan sama saja, aturan tersebut tak lain hanyalah sebuah coretan diatas kertas putih yang tak ternilai apa-apa. Di sini penyusun menggunakan Putusan Nomor 244/Pid 2013/P.T.Smg, sebagai bahan analisis praksis untuk menilai sejauh mana perlindungan, dan perolehan hak difabel selama berhadapan dengan hukum mulai dari pendampingan hingga hak-hak yang harus didapatkan oleh korban atau saksi termasuk Restitusi (ganti rugi). Ganti rugi menjadi penting karena hal tersebut menjadi salah satu point convensi internasional PBB yaitu The Declaration of Basic Principles of Justice for Victims of Crime and Abuse of Power. yang harus diperjuangkan untuk diberikan kepada korban kejahatan, apa lagi korban di sini kaum rentan yang pada dasarnya sebelum menjadi korban kejahatan pun harus mendapatkan perlindungan.

Secara umum hal yang biasanya terjadi terhadap difabel bahwa terkadang hukum menganggap kalangan difabel adalah cacat hukum karena

\footnotetext{
${ }^{8}$ Metrotv News, Kamis, 4 Desember 2014. Pukul 19.00 WIB.
} 
difabel berada dalam pengampuan dan kesaksiannya diragukan. Mekanisme dan prosedur hukum yang tidak mengakomodir kebutuhan khusus difabel, termasuk aksesibilitas, penerjemah bahasa isyarat, sebagai kendala serius dalam upaya penegakan hukum. Standarisasi keabsahan saksi dan bukti juga menjadi salah satu faktor. Selain itu metode introgasi dan investigasi aparat penegak hukum yang saklek dapat pula berpengaruh pada kelengkapan informasi yang berhasil diperoleh dari difabel korban kekerasan atau sebagai saksi. ${ }^{9}$

Setelah mengaji Putusan Nomor 244/Pid 2013/P.T.Smg, ternyata tidak jauh berbeda. Baik kepolisian dan kejaksaan masih tertatih dan kurang memperhatikan hak-hak korban. Menurut Purwanti, ${ }^{10}$ mengatakan bahwa pada Undang-Undang Nomor 19 Tahun 2011 tentang Pengesahan Convention on The Rights of Person with Disabilities (Konvensi Mengenai Hak-Hak Penyandang Disabilitas) pada kenyataan telah dirasakan di lapangan belum mengatur secara detail, hanya secara garis besar saja, semua hak-hak disabilitas memang sudah tertuang di Konvensi tersebut, namun ironisnya belum ada implementasi yang nyata. Di dalam kasus ini korban adalah difabel, dan seharusnya korban mendapatkan seorang ahli baik psikologi maupun dokter. Namun, pada kenyataannya, yang mendorong untuk dihadirkannya para ahli supaya dapat diperiksa secara psikologi maupun medis, justru inisiatifnya dari pendamping bahkan biaya pun ditanggung oleh pendamping sendiri, sedangkan kepolisian hanya menanggung biasa visum saja. ${ }^{11}$

Dengan adanya keterangan tersebut gambaran bahwa kurangnya perhatian khusus terhadap difabel, dan tidak dipersamakan dengan masyarakat seperti biasa di hadapan hukum. Bahkan dari institusi kejaksaan pun enggan untuk mengungkapkan identitas korban, yang senyatanya dapat diketahui jika secara tlaten dan sabar menggunakan penerjemah tuna rungu. Kondisi psikologi seperti trauma korban sering kali dinegasikan karena hakim kurang cakap dalam menangani kasus difabel ini. Di Australia itu ada praktik yang sangat bagus sekali, misalnya difabel mental intelektual yang sangat sensitif dengan trauma di persidangan itu mereka tidak dipertemukan dengan tersangka dan kesaksian itu cukup direkam satu kali kemudian ketika

9 Makalah disampaikan oleh Purwanti, Sasana Integrasi Dan Advokasi Difabel pada WORKSHOP PENULISAN BUKU "Pemenuhan Hak Atas Peradilan yang Fair Bagi Penyandang Disabilitas" di Hotel Grand Quality Yogyakarta, 12 - 13 Desember 2013.

${ }^{10}$ Purwanti adalah seorang program officer, atau para legal sekaligus sebagai koordinator aliansi dari lembaga Sasana Integrasi dan Advokasi Difabel (SIGAB) Yogyakarta, dan sebagai pendamping utama korban.

${ }^{11}$ Wawancara dilakukan di kantor SIGAB Yogyakarta, Senin, 1 September 2014 pukul 10.30 WIB. 
diperlukan hanya diulang saja. ${ }^{12} \mathrm{Hal}$ ini cukup efektif dan memberikan ketenangan korban dalam memberikan keterangan yang sebenarnya tanpa ada tekanan psikis dari sudut pandang korban.

Setelah menelusuri dan menelaah Putusan Nomor 244/Pid 2013/P.T.Smg dengan detail dan cermat ternyata masih banyak ditemukan kurangnya poin-poin perlindungan yang diakomodir dan dilaksanakan sebagaimana amanat Undang-Undang Nomor 13 tahun 2006 tentang Perlindungan Saksi dan Korban. Adapun rincian pemenuhan hak dan perlindungan korban difabel sesuai dengan Pasal 5 ayat (1) Undang-Undang Nomor 13 tahun 2006 tentang Perlindungan Saksi dan Korban tersebut adalah sebagai berikut;

\begin{tabular}{|c|c|c|}
\hline No. & Jenis Perlindungan & Keterangan \\
\hline 1. & $\begin{array}{l}\text { memperoleh perlindungan atas } \\
\text { keamanan pribadi, keluarga, } \\
\text { dan harta bendanya, serta } \\
\text { bebas dari ancaman yang } \\
\text { berkenaan dengan kesaksian } \\
\text { yang akan, sedang, atau telah } \\
\text { diberikannya; }\end{array}$ & sudah terpenuhi \\
\hline 2. & $\begin{array}{l}\text { ikut serta dalam proses } \\
\text { memilih dan menentukan } \\
\text { bentuk perlindungan dan } \\
\text { dukungan keamanan; }\end{array}$ & $\begin{array}{l}\text { tidak terpenuhi, karena dari pihak } \\
\text { korban sendiri mengalami } \\
\text { kesulitan, dan hanya pendamping } \\
\text { saja yang dapat menentukan } \\
\text { bentuk perlindungan, namun } \\
\text { masih saja kurang maksimal. }\end{array}$ \\
\hline 3. & $\begin{array}{l}\text { memberikan keterangan tanpa } \\
\text { tekanan; }\end{array}$ & $\begin{array}{l}\text { korban merasa tertekan karena } \\
\text { pertanyaan yang diberikan melulu } \\
\text { menyebut nama pelaku dan } \\
\text { menurut pendamping, korban } \\
\text { sentak akan menangis }\end{array}$ \\
\hline 4. & mendapat penerjemah; & $\begin{array}{l}\text { sudah terpenuhi, namun kurang } \\
\text { maksimal, }\end{array}$ \\
\hline 5 . & $\begin{array}{l}\text { bebas dari pertanyaan yang } \\
\text { menjerat; }\end{array}$ & belum terpenuhi; \\
\hline 6. & $\begin{array}{lr}\text { mendapatkan } & \text { informasi } \\
\text { mengenai } & \text { perkembangan } \\
\text { kasus; } & \\
\end{array}$ & sudah terpenuhi \\
\hline
\end{tabular}

12 Jurnal ditulis oleh Ari Wijayanto, Upaya Perlindungan Hukum Terhadap Kaum Difabel Sebagai Korban Tindak Pidana, (Yogyakarta: Universitas Atmajaya, 2013). 


\begin{tabular}{|c|c|c|}
\hline 7. & $\begin{array}{l}\text { mendapatkan informasi } \\
\text { mengenai putusan pengadilan; }\end{array}$ & Sudah terpenuhi \\
\hline 8. & $\begin{array}{ll}\text { mengetahui dalam } & \text { hal } \\
\text { terpidana dibebaskan; } & \end{array}$ & sudah terpenuhi \\
\hline 9. & mendapat identitas baru; & $\begin{array}{llr}\text { belum } & \text { terpenuhi, } & \text { untuk } \\
\text { mengungkap identitas korban saja } \\
\text { dari pihak kejaksaan } & \text { merasa } \\
\text { kesulitan karena } & \text { kurang } \\
\text { pendampingan dari } & \text { pihak } \\
\text { penerjemah; } & & \\
\end{array}$ \\
\hline 10. & $\begin{array}{l}\text { mendapatkan tempat kediaman } \\
\text { baru; }\end{array}$ & belum terpenuhi \\
\hline 11. & $\begin{array}{l}\text { memperoleh penggantian biaya } \\
\text { transportasi sesuai dengan } \\
\text { kebutuhan; }\end{array}$ & $\begin{array}{l}\text { belum terpenuhi, karena untuk } \\
\text { melakukan visum saja, masih } \\
\text { terkendala biaya, dan dengan } \\
\text { biaya sendiri }\end{array}$ \\
\hline 12. & $\begin{array}{l}\text { mendapat nasihat hukum; } \\
\text { dan/atau } \\
\text { memperoleh bantuan biaya } \\
\text { hidup sementara sampai batas } \\
\text { waktu perlindungan berakhir. }\end{array}$ & $\begin{array}{l}\text { belum terpenuhi, nasehat hukum } \\
\text { memang sudah terpenuhi, namun } \\
\text { dalam hal biaya hidup sementara } \\
\text { memenuhi. }\end{array}$ \\
\hline
\end{tabular}

Dari jenis perlindungan yang sudah dipaparkan di atas masih banyak ditemukan poin perlindungan yang belum terpenuhi, dan ternyata tidak semua term perlindungan yang tertera dalam undang-undang dapat dikontekstualisasikan pada kasus yang korbannya seorang difabel. Selain itu, landasan hukum yang digunakan untuk menjerat pelaku adalah dengan Kitab Undang-Undang Hukum Pidana (KUHP), artinya original intent dari rumusan pasal-pasal yang ada di dalam KUHP tersebut sebenarnya mempengaruhi putusan Hakim. Jadi merupakan pilihan hakim apakah akan memutus sesuai dengan bunyi pasal atau menelaah lebih dalam nilai-nilai Hukum pidana positif yang terkandung dalam butuh KUHP itu sendiri. Sesungguhnya sejalan dengan Barda Nawawi bahwa dalam hukum pidana positif perlindungan korban lebih banyak merupakan perlindungan abstrak atau perlindungan tidak langsung, artinya dengan adanya berbagai banyak perumusan tindak pidana dalam peraturan perundang-undangan selama ini, berarti pada hakikatnya telah ada perlindungan hukum dan hak asasi korban. ${ }^{13}$

${ }^{13}$ Barda Nawawi Arief, Beberapa Aspek Kebijakan Penegakkan Dan Pengembangan Hukum Pidana, (Bandung: Citra Aditya Bakti, 1998), hlm. 55. 
Rumusan pasal yang digunakan dalam kasus tersebut menunjukkan bahwa tidak adanya berbedaan delik yang dilakukan antara pelaku biasa dengan penyandang cacat. Putusan hakim pun lebih condong pada corak putusan yang berupa Ia bouche des lois atau sering kita dengar bahwa hakim sebagai corong undang-undang. Untuk menciptakan rasa keadilan bagi kaum-kaum difabel perlu adanya sebuah trobosan hukum baru bagi para catur wangsa penegak hukum, khususnya hakim untuk berani memberikan putusan yang lebih humanis, dan bahkan dapat memberikan beban restitusi tersendiri kepada terpidana yang dicantumkan pada amar putusannya.

\section{Penutup}

\section{Simpulan}

Setelah melakukan menelusuran dan kajian Putusan Nomor 244/Pid 2013/P.T.Smg, bahwa kepolisian dan kejaksaan masih tertatih dan kurang memperhatikan hak-hak korban. Perlindungan terhadap korban sebagaimana yang tertera pada Undang-Undang Nomor 13 tahun 2006 tentang Perlindungan Saksi dan Korban masih banyak yang belum terpenuhi, selain karena keterbatan ahli, dan juga tidak semua jenis perlindungan dapat di kontekstualisasikan pada kasus yang korbannya seorang difabel. UndangUndang Nomor 19 Tahun 2011 tentang Pengesahan Convention on The Rights of Person with Disabilities (Konvensi Mengenai Hak-Hak Penyandang Disabilitas) pada kenyataan telah dirasakan di lapangan belum mengatur secara detail, hanya secara garis besar saja, semua hak-hak disabilitas memang sudah tertuang di Convensi tersebut, namun ironisnya belum ada implementasi yang nyata. Di dalam kasus ini korban adalah difabel, dan seharusnya korban mendapatkan seorang ahli baik psikologi maupun dokter. Namun, pada kenyataannya, yang mendorong untuk dihadirkannya para ahli supaya dapat diperiksa secara psikologi maupun medis, justru inisiatifnya dari pendamping bahkan biaya pun ditanggung oleh pendamping sendiri, sedangkan kepolisian hanya menanggung biasa visum saja.

\section{Daftar Pustaka}

\section{A. Buku}

Arief, Barda Nawawi, 1998, Beberapa Aspek Kebijakan Penegakkan Dan Pengembangan Hukum Pidana, Bandung: Citra Aditya Bakti.

Gosita, Arif, 1983, Masalah Korban Kejahatan Edisi Pertama, Jakarta: Akademika Pressindo.

Magnis, Franz; Suseno, 1993, Etika Politik: Prinsip Moral Dasar Kenegaraan Modern, Jakarta: Gramedia. 
Martitah, 2013, Dari Negative Legislature Ke Positive Legislature, Jakarta: Mahkamah Konstitusi Press, hlm. 63.

Muladi; Arief, Barda Nawawi, 2010, Bunga Rampai Hukum Pidana, Bandung: Alumni.

\section{B. Lain-lain}

Jurnal ditulis oleh Ari Wijayanto, Upaya Perlindungan Hukum Terhadap Kaum Difabel Sebagai Korban Tindak Pidana, Universitas Atmajaya Yogyakarta, 2013

Metrotv News, Kamis, 4 Desember 2014. Pukul 19.00 WIB

Makalah disapaikan oleh Purwanti, Sasana Integrasi Dan Advokasi Difabel pada WORKSHOP PENULISAN BUKU "Pemenuhan Hak Atas Peradilan yang Fair Bagi Penyandang Disabilitas" di Hotel Grand Quality Yogyakarta, 12 - 13 Desember 2013.

Diakses pada situs www.SinarHarapan.com, oleh Agus Wibowo, dengan tema Diskriminasi Pendidikan Bagi Kaum Difabel, Kamis, 4 Desember 2014. 